\title{
Assessment of Mobbing Behaviors Exposed by the Academic Personnel Working in a University, in Turkey
}

Vesile Şenol $^{1^{*}}$, Ebru Avsar ${ }^{2}$, Raziye Peksen Akca ${ }^{3}$, Mahmut Argun ${ }^{4}$, Levent Avsarogulları ${ }^{5}$ and Fahrettin Kelestimur ${ }^{6}$

${ }^{1}$ Erciyes University, Health Services Vocational College, Kayseri, Turkey,

${ }^{2}$ Kayseri Bar Associations, Turkey

${ }^{3}$ Develi Vocational School, Erciyes University, Turkey

${ }^{4}$ Orthopaedia and Traumatologyi school of Medicine, Erciyes University, Turkey

${ }^{5}$ Emergency Medicine, School of Medicine, Erciyes University, Turkey

${ }^{6}$ EndocrinologyDepartment, School of Medicine, Erciyes University, Turkey

*Corresponding author: Vesile Senol, Erciyes University, Saglık Hizmetleri Meslek Yüksekokulu, 38039 Kayseri-Turkey, Tel: 903524375279 / 40011 , Fax: 903524375936, E-mail: vsenol@erciyes.edu.tr

Received Date: September 2, 2014, Accepted Date: November 25, 2014, Published Date: December 3, 2014

Copyright: $\odot$ 2015, Vesile Şenol et al., This is an open-access article distributed under the terms of the Creative Commons Attribution License, which permits unrestricted use, distribution, and reproduction in any medium, provided the original author and source are credited.

\begin{abstract}
Objective: To determine psychological violence behaviors (mobbing) exposed by academic personnel working in Erciyes University, Turkey.

Methods: A questionnaire-based cross sectional study was performed in June 2010 in Erciyes University. No sampling methods were used, questionnaires were delivered by mail to all academicians and 450 of 850 (53.0\%) questionnaires were returned. We used the Mobbing Perception Scale (MPS) for data collection.

Results: A total of $58.2 \%$ of the academicians experienced recurrent physiological violence at least once a week in the workplace and $16.6 \%$ stated that they were directly exposed to mobbing behavior every day (>1 point) in the past year, $44.7 \%$ reported "assault to their professional status", $42.8 \%$ reported "assault to personality", $39.9 \%$ reported "isolation from work", $13.0 \%$ reported "direct negative behavior". The most commonly (30.4\%) experienced behavior was; "groundless talk about the person in question". Mobbing was not associated with demographic and professional variables. The main source of mobbing was the managers. Also $68.0 \%$ of the victims resorted to passive defense strategies, and only $2.5 \%$ took legal action.

Conclusion: Workplace mobbing is a critical problem for academicians in our university. The level of directly mobbing behavior was substantially high. The most common threatening behavior was "assault to professional status". The primary mobbers were the managers. A great of majority academicians had not been received professional help and they internalized the mobbing. The findings indicated that levels of awareness of mobbing have increased among academicians.
\end{abstract}

Keywords: Psychological violence (Mobbing); Academicians; Workplace

\section{Introduction}

Mobbing is a kind of psychological violence, commonly encountered in disorganized work places, and usually targets bright, successful, and creative people. It is the most serious and destructive kind of violence and affects the whole of society, irrespective of age, race, language, educational level, or title [1]. Nowadays mobbing has become an important part of daily life; it has also become a potential health and occupational risk factor in both public and private sectors. Mobbing is a continuous systematic and intentional intimidating behavior, through psychological methods, exerted by a group or someone who has authority over others, within a hierarchically structured group, in a lower status [2,3]. The determinants of mobbing behavior are consistency and frequency. In order to specify a behavior as mobbing, it has to be repeated at least once a week and for at least 6 months [4]. There are some important aspects regarding mobbing; these include communication, social relationships, social status, the quality of private and professional life, assaults targeting health, the effects of the assaults upon the victim, the amount of damage to the victim, and persistence in the behavior $[1,5]$.

Apart from the losses the victim endures regarding social prestige, self-confidence, and self-respect, there are also consequences such as secondary long term severe damages to institutional structure and environment. Another social aspect of mobbing is the increased economical cost due to work and safety loss, workdays lost, decrease in productivity and performance, decrease in work quality, unemployment, early retirement, and loss of institutional respect [6]. Mobbing can be vertical and horizontal [6,7]. Vertical mobbing is the psychological violence within an institution, inflicted from the top executives on people below them or vice versa. Usually the person inflicting mobbing is professionally above the victim. These people usually use mobbing as a guarantee to continue their own profession within competitive environment [8]. Horizontal mobbing is the mobbing between colleagues at the same level. The person inflicting the mobbing and the victim can be work friends, in similar positions, 
with the same opportunities [9]. In mobbing from below upwards, the person inflicting mobbing is in a lower professional position to the victim [10]. Studies regarding mobbing started in 1990 in America and Europe, and the most remarkable and important development was the foundation of a mobbing clinic in 1992 in Germany, with the help of Leymann [11]. Westhues wrote a book about intimidation at universities [12]. On the other hand, in Turkey, this topic was only opened to discussion with its differing dimensions and at a cognitive level around the year 2000, and the number of empirical studies have substantially increased in the past years $[4,13]$.

Usually, the mobbing behavior exerted is aimed at qualified people and does not show any distinction in place, time or profession $[1,3]$. All the same, it is a known fact that it is experienced more frequently in institutions involved in the service sector, in universities and in the health sector, which usually adopt a more authoritarian management style $[1,14,15]$. The factors that enhance the spread of mobbing among the academicians can be listed as follows: The general academic hierarchical manners in universities, precarious work situation, conflicts in professional life due to limited academic positions, competition experienced to make progress in one's career, unjust success evaluation, stress experienced during the process of fulfilling academic advancement criteria while under difficult working conditions, difficulty in attaining tenure in associate professor and professor positions and the absolute authority granted to managers by the law $[1,16]$. The severe power imbalance between managers and subordinates results in the acceptance by the victim of his/her role within the play, the rules of which are established by the perpetrators [3]. Therefore, those academicians that suffocate under this authority and/or the high academic expectations of the managers in the university, either become submissive, or they helplessly internalize this mobbing, and start to see it as a natural, inevitable part of their profession. Those that cannot adopt this attitude are the ones upon which mobbing is inflicted [17,18]. According to Einersan [16], in academic environments with highly educated workers, the workers start to compete with each other in order to gain more status and to attain the academic superior's sympathy and approval, aiming to increase their chances of progressing in their careers, and finally, in this competitive environment, they start to exert psychological violence on each other. In many countries mobbing is the most frequently encountered type of violence. It was reported that $53 \%$ of workers in the U.K, and $18 \%$ of those in Denmark were exposed to psychological violence $[6,13]$.Lewis stated that $18 \%$ of academicians in the U.K have been exposed to direct mobbing behavior [19]. Psychological violence is seen more intensely among health sector workers. The prevalence rates of verbal violence reported from the U.K, Hong Kong, and China were between 43-73\%. In the 'Work Place Violence in Health Institutions'2002 reports of the WHO, ILO and ICN, the rates of exposure to verbal violence were between $27-67 \%$ [20,21].

In Turkey, there are various studies about mobbing in which the issue of mobbing is more analyzed in industrial workplaces rather than in universities. So there is no sufficient information about academic mobbing in Turkish literature. The rates of mobbing reported in studies from Turkey are similar to those in international studies. These studies show that the rate of mobbing was $42.0 \%$ in Turkey, and $70.0 \%$ of these victims never mentioned the problem to anyone [2]. On the other hand, in limited studies performed in universities, it has been established that $17-29 \%$ of the academicians are victims of direct mobbing $[1,19,20,22]$. We believe this paper could be one of the important studies that might fill out lack of data about academic mobbing in our country. The critical points in the struggle against mobbing and its social, personal and institutional consequences are to improve workplace standards, and prevent social exclusion. In order to establish and guarantee an honorable and qualified academic life, all personnel should be informed about the culture and standards of the institution, and about the nature of mobbing, thus enhancing self and institutional awareness. In addition, active defense strategies should be put into action and, in evaluating academic advancement criteria, ethical principles and worthiness should be prioritized, and the knowledge and skills of the managers regarding conflicts and communication should be increased $[17,23]$. The aim of this study is to determine prevalence of mobbing behavior exposed by the academics in their workplace, if there is any relationship between demographic and professional characteristics and being victimized, and who perpetrators are.

\section{Material and Methods}

\section{Subjects}

This cross-sectional study was carried out in Erciyes University between May-June 2010. No sampling method was used, questionnaires were delivered by department secretaries to all academicians and 450 out of 850 (53.0\%) questionnaires were returned. Thirty six questionnaires were excluded due to the missing data. The statistical evaluation was performed upon the data of 414 questionnaires. Ninety nine of the participants (23.9\%) were working in the social sciences faculties (economy, fine arts, education, communication, law school), 147 (35.5\%)were in the health sciences schools such as medicine, dentistry, veterinary, pharmaceutics, and $168(40.6 \%)$ were in the technical sciences schools such as engineering faculties and graduate school in economy and administration fields of the academicians $84(20.3 \%)$ were professor, $78(20.2 \%)$ were associate professors, $114(27.6 \%)$ were assistant professors, and $138(33.3 \%)$ were lecturers.

\section{Questionnaires}

The data were collected by a questionnaire comprising three parts. The first part was related to socio-demographic and professional characteristics (age, gender, marital status, number of children, academic degree, the duration of working in the profession, course load per week, administrative position); in the second part included Mobbing Perception Scale (MPS) to assess mobbing behaviors. The Turkish adaptation of the reliability and validity study was done by Yildirim et al. [24]. MPS is -a six fold Likert type-including 33 items classified into 4 dimensions. The 11 items $(17-20,22-26,30,31)$ refer to "Isolation from work", the 9 items $(5,10-14,16,21,29)$ refer to "assault to professional status", the 9items $(1-4,6-9,15)$ refer to "assault to personality", and the 4 items $(27,28,32,33)$ refer to "direct negative behaviors". The answers to the scale were scored as follows; $0=$ never or scarcely ever, $1=$ once, $2=\mathrm{a}$ few times, $3=$ sometimes, $4=$ often, $5=$ always. All the items in the scale are positive and none are reverse scored. The participants were asked to state the frequency of exposure to the mobbing behavior in the scale within the past 12 months, and to define the people who inflicted the mobbing behavior. The answers between "at least once" and "always" were united and classified as "people who were exposed to mobbing" but the subject who selected "never" were classified as "people who were not exposed to mobbing". The total scale score was calculated by the sum of the points from the individual items. The Cronbach's a coefficient for final scale was 0.97 , 
Citation: Senol V, Avsar E, Peksen Akca R, Argun M, Avsarogullari L (2015) Assessment of Mobbing Behaviors Exposed by the Academic Personnel Working in a University, in Turkey . J Psychiatry 18: 212. doi:10.4172/2378-5756.1000212

Page 3 of 10

sub scales for "personal isolation from work" was 0.92 , for "assault to professional status" was 0.91 , for "assault to personality" 0.91 and for "direct negative behaviors" was 0.70 in the present study. The total score obtained from the scale is divided the number of items, and if the result is $>1$ point, it is presumed that the person is exposed to directly psychological violent behavior at work. The third part of the questionnaire contained questions on the perpetrators of mobbing, the defense strategies used by the victims until now when exposed to mobbing behaviors.

\begin{tabular}{|c|c|c|c|c|c|c|c|}
\hline \multirow[b]{3}{*}{ Characteristics } & \multicolumn{6}{|c|}{ Exposure to mobbing* } & \multirow[t]{3}{*}{ Statistical assessment } \\
\hline & \multicolumn{2}{|c|}{ Presence } & \multicolumn{2}{|c|}{ Absence } & \multicolumn{2}{|c|}{ Total } & \\
\hline & $\mathrm{n}$ & $\%$ & $n$ & $\%$ & $\mathrm{n}$ & $\%$ & \\
\hline \multicolumn{8}{|l|}{ Gender } \\
\hline Female & 155 & 60.8 & 100 & 39.2 & 255 & 61.6 & \multirow[b]{2}{*}{$X^{2}=1.594, p=0.220$} \\
\hline Male & 86 & 54.1 & 73 & 45.9 & 159 & 38.4 & \\
\hline \multicolumn{8}{|l|}{ Age groups (year) } \\
\hline $22-31$ & 36 & 60 & 24 & 40 & 60 & 14.5 & \multirow[b]{4}{*}{$X^{2}=2.953, p=0.405$} \\
\hline $32-41$ & 103 & 57.5 & 76 & 42.5 & 179 & 43.2 & \\
\hline $42-51$ & 75 & 62.5 & 45 & 37.5 & 120 & 29 & \\
\hline $52-67$ & 27 & 49.1 & 28 & 50.9 & 55 & 13.3 & \\
\hline Age in years (mean $\pm S D$ ) & \multicolumn{3}{|c|}{$40.22 \pm 9.10$} & \multicolumn{3}{|c|}{$41.22 \pm 9.26$} & $t=1.086, p=0.282$ \\
\hline \multicolumn{8}{|l|}{ Marital status } \\
\hline Single/widowed-divorced & 49 & 62 & 30 & 38 & 79 & 19.1 & \multirow[b]{2}{*}{$X^{2}=0.657, p=0.449$} \\
\hline Married & 192 & 57.3 & 143 & 42.7 & 335 & 80.9 & \\
\hline \multicolumn{8}{|l|}{ Academic degree } \\
\hline Professor & 47 & 56 & 37 & 44 & 84 & 20.3 & \multirow[b]{4}{*}{$X^{2}=0.323, p=0.959$} \\
\hline Associate Professor & 48 & 61.5 & 30 & 38.5 & 78 & 18.8 & \\
\hline Assistant Professor & 66 & 57.9 & 48 & 42.1 & 114 & 27.6 & \\
\hline Lecturer & 80 & 58 & 58 & 42 & 138 & 33.3 & \\
\hline \multicolumn{8}{|l|}{ Place of work } \\
\hline Health Sciences Faculties & 93 & 63.3 & 54 & 36.7 & 147 & 35.5 & \multirow[b]{3}{*}{$X^{2}=1.993, p=0.371$} \\
\hline Social Sciences Faculties & 55 & 55.6 & 44 & 44.4 & 99 & 23.9 & \\
\hline Technical Sciences Faculties & 93 & 55.4 & 75 & 44.6 & 168 & 40.6 & \\
\hline \multicolumn{8}{|l|}{ Administrative position } \\
\hline Presence & 90 & 65.2 & 48 & 34.8 & 138 & 33.3 & \\
\hline Absence & 151 & 54.7 & 125 & 45.3 & 276 & 66.7 & $x^{2}=3.648, p=0.058$ \\
\hline Duration of work in profession(years) (mean \pm SD) & \multicolumn{3}{|c|}{$15.64 \pm 9.02$} & \multicolumn{3}{|c|}{$16.73 \pm 9.49$} & $t=1.177, p=0.240$ \\
\hline $\begin{array}{l}\text { Service period in current instituon (years) (mean } \pm \\
\text { SD) }\end{array}$ & \multicolumn{3}{|c|}{$11.56 \pm 8.38$} & \multicolumn{3}{|c|}{$11.80 \pm 8.46$} & $t=0.282, p=0.778$ \\
\hline Course load per week (mean $\pm S D$ ) & \multicolumn{3}{|c|}{$18.85 \pm 9.69$} & \multicolumn{3}{|c|}{$19.89 \pm 8.95$} & $t=1.122, p=0.262$ \\
\hline
\end{tabular}

Table1: Exposure to mobbing from the mobbing scale according to personal and professional characteristics, ${ }^{\star}$ Exposure to mobbing: Presence: scores of MPS=1.0-159 points, Absence: Scores of MPS= 0 point. 
Citation: Senol V, Avsar E, Peksen Akca R, Argun M, Avsarogullari L (2015) Assessment of Mobbing Behaviors Exposed by the Academic Personnel Working in a University, in Turkey . J Psychiatry 18: 212. doi:10.4172/2378-5756.1000212

Page 4 of 10

\begin{tabular}{|c|c|c|c|}
\hline \multirow{2}{*}{ Mobbing Behaviors } & Victims & Non-victims & MPS scores \\
\hline & n (\%) & $\mathrm{n}(\%)$ & Mean \pm SD \\
\hline Personal Isolation from Work & $165(39.9)$ & $68.5(60.1)$ & $6.84 \pm 10.18$ \\
\hline Not being given an opportunity to prove oneself & $81(19.6)$ & $333(80.4)$ & $0.93 \pm 1.56$ \\
\hline Criticised and rejected because of the decisions and recommendations of others & $92(22.2)$ & $322(77.8)$ & $0.90 \pm 1.39$ \\
\hline Having their duties been taken from them and given to subordinates & $49(11.8)$ & $365(88.2)$ & $0.48 \pm 1.16$ \\
\hline Being inspected by others in lower positions & $47(11.4)$ & $367(88.6)$ & $0.48 \pm 1.19$ \\
\hline Not being informed about social meetings that are organized & $70(16.9)$ & $344(83.1)$ & $0.67 \pm 1.27$ \\
\hline Not being able to get an answer to a request for a meeting & $49(11.8)$ & $365(88.2)$ & $0.53 \pm 1.24$ \\
\hline Being treated in the workplace as if they are invisible and don't exist & $69(16.7)$ & $345(83.3)$ & $0.83 \pm 1.47$ \\
\hline Frequently being interrupted while speaking & $66(15.9)$ & $348(84.1)$ & $0.64 \pm 1.24$ \\
\hline Not receiving an answer to an e-mail and/or telephone calls & $41(9.9)$ & $373(90.1)$ & $0.41 \pm 1.09$ \\
\hline Being pressured to leave the job or change workplace & $37(8.9)$ & $377(91.1)$ & $0.08 \pm 0.28$ \\
\hline Having information, documents, and material needed for work hidden from them & $48(19.9)$ & $366(88.4)$ & $0.50 \pm 1.21$ \\
\hline Assault to Professional Status & $185(44.7)$ & $229(55.3)$ & $6.04 \pm 8.45$ \\
\hline Always having errors found in their work and work results & $63(15.2)$ & $351(84.8)$ & $0.64 \pm 1.29$ \\
\hline Being held responsible for work above capacity & $34(8.2)$ & $380(91.8)$ & $0.32 \pm 0.94$ \\
\hline Being held responsible for bad results in work done with others & $61(14.7)$ & $353(85.3)$ & $0.53 \pm 1.15$ \\
\hline Being blamed for things they are not responsible for & $83(20.0)$ & $331(80.0)$ & $0.69 \pm 1.20$ \\
\hline Constant questioning of professional adequacy after each work completed & $47(11.4)$ & $367(88.6)$ & $0.45 \pm 1.09$ \\
\hline Considering the work they have done as not valuable and unimportant & $88(21.3)$ & $326(78.7)$ & $0.96 \pm 1.51$ \\
\hline Constant negative evaluation of their performance & $60(14.5)$ & $354(85.5)$ & $0.62 \pm 1.29$ \\
\hline Having them feel they themselves or their work are being controlled & $113(27.3)$ & $301(72.7)$ & $1.19 \pm 1.57$ \\
\hline Being forced to do a job that will negatively affect their self-confidence & $60(14.5)$ & $354(85.3)$ & $0.59 \pm 1.23$ \\
\hline Assault to Personality & $177(42.8)$ & $73.4(57.2)$ & $5.58 \pm 7.91$ \\
\hline Facing behavior such as slamming fist on a table & $38(9.2)$ & $376(90.8)$ & $0.28 \pm 0.80$ \\
\hline Having untrue things said about them & $126(30.4)$ & $288(69.6)$ & $1.19 \pm 1.42$ \\
\hline Being verbally threatened & $61(14.7)$ & $353(85.3)$ & $0.51 \pm 1.11$ \\
\hline $\begin{array}{l}\text { Having someone speak about you in a belittling and demeaning manner in the presence } \\
\text { of others }\end{array}$ & $91(22.0)$ & $323(78.0)$ & $0.81 \pm 1.27$ \\
\hline $\begin{array}{l}\text { Having someone behave in a demeaning manner (using body language) to them in the } \\
\text { presence of others }\end{array}$ & $87(21.0)$ & $327(79.0)$ & $0.85 \pm 1.35$ \\
\hline Having false rumors said about their private life & $51(12.3)$ & $363(87.7)$ & $0.44 \pm 1.05$ \\
\hline Having someone suggest that they are not psychologically well & $33(8.0)$ & $381(92.0)$ & $0.31 \pm 0.93$ \\
\hline Having their honesty and reliability questioned & $71(17.1)$ & $343(82.9)$ & $0.70 \pm 1.33$ \\
\hline Having unfair reports written about them & $52(12.5)$ & $362(87.4)$ & $0.46 \pm 1.11$ \\
\hline Direct Negative Behaviors & $54(13.0)$ & $360(87.0)$ & $1.04 \pm 2.62$ \\
\hline
\end{tabular}




\begin{tabular}{|l|l|l|l|}
\hline Being exposed to physical violence & $13(3.1)$ & $401(96.9)$ & $0.08 \pm 0.47$ \\
\hline Harmful behavior to personal belongings & $19(4.6)$ & $395(95.4)$ & $0.20 \pm 0.83$ \\
\hline People leaving intentionally the area they happen to enter & $29(12.0)$ & $385(93.0)$ & $0.29 \pm 0.95$ \\
\hline Preventing or forbidding co-workers from talking with you & $37(8.9)$ & $377(91.1)$ & $0.42 \pm 1.19$ \\
\hline Overall Mobbing & $241(58.2)$ & $173(41.8)$ & $19.51 \pm 26.92$ \\
\hline
\end{tabular}

Table 2: The frequency of exposure to mobbing behavior reported by the academicians (n: 414)

\section{Data Collection}

Data were collected between May-June 2010. After the official permission approved by the university administration, all of the academic units were first called and requested to give appointment. After the appointments were arranged, the departments were visited by the researchers on the given dates of appointment. First, the questionnaire forms were delivered to the department secretaries considering numbers of the staff working at those departments. The secretaries then delivered the forms to the academicians. While presenting the forms to the departments, two envelopes with different sizes were used, the bigger one containing the smaller one and the form. Both of which had been closed and sealed. The name, title, affiliation and work place of the academician were previously written on the front face of the outer envelope. The front face of the inner one was left blank. The forms filled out by the academicians within a safe environment and in privacy. They were returned within blank, closed and sealed envelopes to the department secretaries. These closed and sealed envelopes containing the filled questionnaire forms were collected by the researchers from the secretaries a week later. For the forms not submitted, the departments were revisited in the third and fourth weeks. Out of the 850 distributed questionnaires, 450 were answered. Due to the fact that there might be some effects (e.g. the Hawthorne effect) upon the questionnaire related to the awareness of the academicians of the study being performed in the instruction part of the questionnaire forms, they were asked not to write their names on the forms and the envelope at all, and they were clearly informed that the study was utterly on a voluntary-basis-participation and the results would not be used in their professional evaluation.

\section{Statistical Analysis}

The data were analyzed by the Statistical Package for Social Sciences 18.0 (SPSS Inc., Chicago, II., USA) programme. Priority the normality plots with (Shapiro-Wilk) test was performed to test the suitability of the variables for normal distribution. It showed that the data did not fit in a standard distribution curve $(p>0.001)$. Fisher's exact Chisquare $(\chi 2)$ test was used to analyze the frequency exposure to mobbing behavior according to age, gender, marital status, job title, place of work and administrative position. Chi-square test was used also to show relation between mobbing behaviors and those who perpetrators. Descriptive statistics (frequency, percentage, mean and standard deviation) were calculated for quantitave variables. Independent samples t-test was carried out with to determine whether or not there was a difference exposure to mobbing according to age in years, duration of working in profession, service period in current institute, course load per week. A p value $<0.05$ was accepted as significant.

\section{Results}

\section{Socio-demographic and professional characteristics}

The response rate was $53.0 \%$. The mean age was $40.64 \pm 9.25$ years, the majority of the academicians (43.2\%) were in the $31-42$ years age group and $80.9 \%$ were married. Approximately half of the academicians had worked for 11-20 years and 33.3\%of them had administrative positions. Table 1 shows the distribution of the academicians with respect to exposure to mobbing behavior according to socio-demographic and professional characteristics. The rate of exposure to mobbing were not associated with gender $(\chi 2=1.594$, $\mathrm{p}=0.220)$, age groups $(\chi 2=2.953, \mathrm{p}=0.407)$, marital status $(\chi 2=0.657$, $\mathrm{p}=0.526)$, academic degree $(\chi 2=0.323, \mathrm{p}=0.910)$, place of work $(\chi 2=1.993, \mathrm{p}=0.302)$ and administrative position $\left(\chi^{2}=3.648, \mathrm{p}=0.058\right)$. Similarly, the frequency of exposure to mobbing were not different according to mean duration of working in profession $(t=1.177$, $\mathrm{p}=0.240)$, service period in current institution $(\mathrm{t}=0.282, \mathrm{p}=0.778)$ and course load per week $(t=1.122, p=0.262)$.

\section{Mobbing perception among academicians}

Our findings based on own-declaration revealed out that $58.2 \%$ of 414 academicians were exposed to at least one of the 33 types of mobbing behavior defined in the MPS. The distribution of the mobbing behaviors in respect of type and percentage was as follows: "assault to professional status", $44.7 \%$; "assault to personality", $42.8 \%$; "isolation of individual from work", $39.9 \%$ and "direct negative behavior", 13.0\%. The mean total MPS score was $19.51 \pm 26.92$ (min:1, max:159) (Table 2).

\begin{tabular}{|l|l|l|}
\hline Degree of mobbing & Number & $\%$ \\
\hline Never (0-0.25 point) & 114 & 47.3 \\
\hline Once (0.26-0.49 point) & 58 & 24.1 \\
\hline $\begin{array}{l}\text { Sometimes (0.50- } 0.75 \\
\text { point) }\end{array}$ & 16 & 6.6 \\
\hline $\begin{array}{l}\text { Frequently (0.76-1.0 } \\
\text { point) }\end{array}$ & 13 & 5.4 \\
\hline Constantly (>1.0 point) & 40 & 16.6 \\
\hline Total & 241 & 100.0 \\
\hline
\end{tabular}

Table 3: The frequency of exposure to mobbing according to mobbing perception scale (n:241), Mean: $2.22 \pm 1.48$, Median 2.00 ( min: 1.00, $\max : 5.00)$ 
In our study, the most common mobbing behaviors were "groundless talk about the person in question"(30.4\%), "feeling as if the person or their work is being controlled" $(27.3 \%)$ and "criticizing and rejecting the person's decisions and suggestions" (22.2\%). However, the least common (3.1\%)mobbing behavior was "being exposed to physical violence"; $58.7 \%$ of academicians stated that the most common behavior came from co-workers, the second and third common behaviors did from their administrators $(67.0 \%$ and $50.5 \%$ respectively) (Tables 2 and 4).

Considering the level of directly mobbing behavior; a total of $47.3 \%$ of the academicians had not been exposed or almost not exposed to mobbing behavior (mean score: $0-0.25$ points) while $16.6 \%$ of them had been exposed to continuous directly (mean score $>1$ points) mobbing behavior in the previous year. The mean mobbing severity score was $2.22 \pm 1.48$ (Table 3 ).

\section{Perpetrators of mobbing}

In our study vertical mobbing was more frequent: the managers were the ones inflicting psychological violence on subordinates in 23 types of behavior, within the 4 subscales. Among these behaviors, the first three were 'control of the person or their work without the knowledge of the person $(67.0 \%)$ ', 'no response to the requests for talking and meeting (63.3\%)', and 'preventing the co-workers from talking with the academician (62.2\%)'. On the other hand, in 8 types of the behavior, horizontal mobbing was more frequent among colleagues at the same level (53.8\%)', 'belittling behavior towards the academician in front of other people (48.8\%)', 'not notifying the social meetings (45.7\%), 'insinuating that the academician's mental health is deranged (45.5\%)', 'constantly finding faults/mistakes in the work done or the results (43.3\%)', intentionally leaving the environment as soon as the academician arrives (41.4\%)'.The mobbing behavior inflicted by subordinates on the academicians were 'controlling the academician that is in a higher position (10.6\%)', 'hiding any material, documents, and knowledge needed for work (10.4\%)', and 'blaming the academician for things he/she is not responsible for $(9.8 \%)^{\prime}$ ' (Table4).

\section{Defense strategies; what did you do to escape from mobbing?}

It was seen that $37.3 \%$ of the academicians chose to talk with family and friends as a mechanism to deal with mobbing, $30.7 \%$ just tried to ignore it, $15.8 \%$ informed the management in the hope of getting some help, and $2.5 \%$ referred to legal help. Result was that $9.5 \%$ tried other defense strategies, such as, warning the perpetrator, and resorting to violence etc (Table 5).

\section{Discussion}

It has been stated that in career-based academic working environments such as universities, mobbing is seen more prevalent; and academic staff is one of the groups of professionals who is at risk of workplace violence [4]. This study indicated that more than half of the academicians reported that they encountered verbal mobbing behaviors one or more times in the previous year and that majority of these behaviors were from their managers. On the other hand one out of seven academicians (16.6\%) stated that they were directly exposed to psychological violence behaviors. Some recent studies conducted in universities $[17,19,22]$, in accordance with our results, revealed out that the frequency of directly mobbing may reach to $17-29 \%$ in academic personnel. In addition, the frequency of verbal mobbing experienced by academicians in our study was similar to that of another study [20] but it was lower compared to other two studies $[17,25]$.These studies reported that the rate of verbal mobbing behaviors was between $82-90 \%$. Differences in the rate of mobbing in these studies may be a result of using different mobbing definitions, scales $[21,25]$ settings and participants(academic staff, only academic nurses, only physicians [14] and differences perceptions of workplace violence $[1,26,27]$.

In our study, the most common threatening behavior was "assault to professional status", the second common was "assault to personality.", and the least common was "direct negative behavior." In other studies $[17,18,28-30]$ too, in conformity with our results "assault to professional status and personality" were the most common threatening behaviors on academicians. In line with other studies $[17,31]$ in this study threatening behaviors such as "groundless talk about the person in question" and "controlling the person or their work without the knowledge of the person" and "criticizing and rejecting the person's decisions and suggestions" were the most three common exposed mobbing behaviors by academic personnel.

\begin{tabular}{|c|c|c|c|c|c|c|}
\hline \multirow[t]{3}{*}{ Mobbing Behaviors } & \multicolumn{4}{|c|}{ The perpetrators of mobbing } & \multicolumn{2}{|c|}{ Statistical assessment } \\
\hline & \multirow{2}{*}{\begin{tabular}{|l} 
Managers \\
$\%$
\end{tabular}} & \multirow{2}{*}{$\begin{array}{l}\text { Co-workers } \\
\%\end{array}$} & \multirow{2}{*}{$\begin{array}{l}\text { Subordinates } \\
\%\end{array}$} & \multirow{2}{*}{$\begin{array}{l}\text { Others* } \\
\%\end{array}$} & \multirow[b]{2}{*}{$\mathrm{X} 2$} & \multirow[b]{2}{*}{$\mathrm{p}$} \\
\hline & & & & & & \\
\hline \multicolumn{7}{|l|}{ Isolation from work } \\
\hline Not being giving an opportunity to prove themselves & 56.3 & 32.5 & 2.5 & 8.8 & 15.39 & 0.221 \\
\hline $\begin{array}{l}\text { Being criticized and rejected because of decisions and } \\
\text { recommendations }\end{array}$ & 50.5 & 35.2 & 5.5 & 8.8 & 26.77 & 0.008 \\
\hline Having their duties taken from them and given to a subordinate & 59.2 & 24.5 & 6.1 & 10.2 & 21.17 & 0.048 \\
\hline Being inspected by others in a lower positions & 49.9 & 25.5 & 10.6 & 14.9 & 22.31 & 0.034 \\
\hline Not being informed about social meetings that are organized & 38.6 & 45.7 & 4.3 & 11.4 & 12.12 & 0.043 \\
\hline Not being able to get an answer to their request for a meeting & 63.3 & 18.4 & 2.0 & 16.3 & 14.13 & 0.292 \\
\hline
\end{tabular}


Citation: Senol V, Avsar E, Peksen Akca R, Argun M, Avsarogullari L (2015) Assessment of Mobbing Behaviors Exposed by the Academic Personnel Working in a University, in Turkey . J Psychiatry 18: 212. doi:10.4172/2378-5756.1000212

Page 7 of 10

\begin{tabular}{|c|c|c|c|c|c|c|}
\hline $\begin{array}{l}\text { Being treated in their workplace as if they are invisible and don't } \\
\text { exist }\end{array}$ & 47.8 & 37.7 & 5.8 & 8.7 & 27.76 & 0.006 \\
\hline Frequently being interrupted while speaking & 42.4 & 42.4 & 3.0 & 12.1 & 23.49 & 0.024 \\
\hline Not receiving an answer to e-mail and telephone calls & 43.9 & 31.7 & 2.4 & 22.0 & 16.09 & 0.187 \\
\hline Being pressured to leave their job or change workplace & 54.1 & 24.3 & 2.7 & 18.9 & 16.83 & 0.156 \\
\hline $\begin{array}{l}\text { Having information, documents, and material needed for work } \\
\text { hidden from them }\end{array}$ & 43.8 & 35.4 & 10.4 & 10.4 & 20.70 & 0.190 \\
\hline \multicolumn{7}{|l|}{ Assault to Professional Status } \\
\hline Always having errors found in their work and work results & 36.7 & 43.3 & 6.7 & 13.3 & 23.22 & 0.026 \\
\hline Being held responsible for work above capacity & 52.9 & 26.5 & 5.9 & 14.7 & 14.64 & 0.262 \\
\hline Being held responsible for bad results in work done with others & 39.3 & 39.3 & 9.8 & 11.5 & 21.40 & 0.045 \\
\hline Being blamed for things they are not responsible for & 34.1 & 36.6 & 9.8 & 19.5 & 24.29 & 0.019 \\
\hline $\begin{array}{l}\text { Constant questioning of professional adequacy after each work } \\
\text { completed }\end{array}$ & 44.7 & 40.4 & 4.3 & 10.6 & 9.93 & 0.622 \\
\hline $\begin{array}{l}\text { Considering the work they have done as not valuable and } \\
\text { unimportant }\end{array}$ & 44.3 & 29.5 & 8.0 & 18.2 & 22.56 & 0.070 \\
\hline Constant negative evaluation of their performance & 58.3 & 25.0 & 5.0 & 11.7 & 21.78 & 0.040 \\
\hline $\begin{array}{l}\text { Having them feel they themselves or their work are being } \\
\text { controlled }\end{array}$ & 67.0 & 21.4 & 7.1 & 4.5 & 8.55 & 0.740 \\
\hline $\begin{array}{l}\text { Being forced to do a job that will negatively affect their self- } \\
\text { confidence }\end{array}$ & 58.3 & 20.0 & 6.7 & 15.0 & 22.42 & 0.033 \\
\hline \multicolumn{7}{|l|}{ Assault to Personality } \\
\hline Facing behavior such as slamming fist on a table & 52.6 & 26.3 & 5.3 & 15.8 & 21.70 & 0.153 \\
\hline Having untrue things said about them & 21.4 & 58.7 & 7.9 & 11.9 & 19.69 & 0.041 \\
\hline Being verbally threatened & 48.3 & 26.7 & 5.0 & 20.0 & 8.62 & 0.735 \\
\hline $\begin{array}{l}\text { Having someone speak about them in a belittling and demeaning } \\
\text { manner in the presence of others }\end{array}$ & 47.3 & 34.1 & 3.3 & 15.4 & \multicolumn{2}{|l|}{22.02} \\
\hline $\begin{array}{l}\text { Having someone behave in a demeaning manner (using body } \\
\text { language) to them in the presence of others }\end{array}$ & 33.8 & 48.8 & 5.8 & 11.6 & \multicolumn{2}{|l|}{17.73} \\
\hline Having false rumors said about their private life & 17.6 & 56.9 & 15.7 & 9.8 & \multicolumn{2}{|l|}{22.58} \\
\hline Having someone suggest that they are not psychologically well & 36.4 & 45.5 & 0.0 & 18.2 & \multicolumn{2}{|l|}{22.58} \\
\hline Having their honesty and reliability questioned & 48.6 & 36.1 & 5.6 & 9.7 & 35.39 & 0.002 \\
\hline Having unfair reports written about them & 57.7 & 15.4 & 7.7 & 19.2 & 14.87 & 0.534 \\
\hline \multicolumn{7}{|l|}{ Direct Negative Behaviors } \\
\hline Being exposed to physical violence & 23.1 & 53.8 & 0.0 & 23.1 & 5.32 & 0.324 \\
\hline Harmful behavior to personal belongings & 42.1 & 21.1 & 0.0 & 36.8 & 13.07 & 0.042 \\
\hline People leaving intentionally the area they happen to enter & 27.6 & 41.4 & 3.4 & 27.6 & 11.09 & 0.521 \\
\hline Preventing or forbidding coworkers from talking with you & 62.2 & 24.3 & 0.0 & 13.5 & 14.40 & 0.072 \\
\hline
\end{tabular}

Table 4: The frequency of exposure to mobbing according to mobbing perception scale (n: 241), Mean: $2.22 \pm 1.48$, Median 2.00 (min: 1.00, max: 5.00) other: Patient, relatives of patient 


\begin{tabular}{|l|l|l|}
\hline \multirow{2}{*}{ Reaction } & \multicolumn{2}{l|}{$\begin{array}{l}\text { Victims of mobbing } \\
\text { (n: 241) }\end{array}$} \\
\cline { 2 - 3 } & Number & $\%$ \\
\hline Talking with family and friends & 90 & 37.34 \\
\hline Pretending nothing had happened & 74 & 30.70 \\
\hline Reporting to the management and getting help from the manager & 38 & 15.76 \\
\hline Taking legal action & 6 & 2.48 \\
\hline Other* & 23 & 9.54 \\
\hline
\end{tabular}

Table 5: Distribution of victims' reactions after exposure to the mobbing behaviors, ${ }^{\star}$ Other: Warning the perpetrators, reacting with violence, reporting to the union, talking with the perpetrators face to face, hiring the mafia, being more careful about communicative styles, solving or handling the problem themselves- defending their living, struggling alone, cursing

According to Leymann's [1] mobbing identification steps we can think that the psychological violence exerted on our academicians has completed the first level of mobbing that is asserting oneself (56.3\%), and trying to prevent the development of communication (62.0-63.0\%), and the second level of mobbing, that is assault to social relationships. It has thus reached the severe mobbing level of the third and fourth degrees. The next stage is that in which direct assault to personal health begins: threat of physical violence, physical damage and sexual harassment $[1,8]$. In this context, in our study, the fact that $3.1 \%$ of the academicians were victims of physical violence, most perpetrators were co-workers, and $5.0 \%$ had experienced damage to their personal belongings, especially from their own managers, show the extent to which violence has reached.

We found that psychological violence seems to be more prevalent among academicians working in healthcare programmes (63.3\%), which is consistent with findings obtained by Yildirim et al. [17] and Aytac et al. [32]. Study results show that workers in the health sector are at a 16 fold risk of being exposed to mobbing behavior compared to other sectors [15,33], 18-37\% of the health professionals are exposed to directly mobbing behavior in the workplace, and $74-91 \%$ were exposed to one or more than one types of mobbing behavior [8]. In the literature, the causal relationship between socio-demographic variables and mobbing has not become clear. Previous studies $[3,17,34]$ show a large variation in the prevalence rates of mobbing according to descriptive characteristics. In our study, exposure to mobbing behavior was not associated with socio-demographic characteristics in accordance with some studies [1,19]. However, some studies $[22,25,18,28,32,35,36]$ reported that being young female, being university educated $[32,35]$ or having lower educational level and being single [15,35] and having more work experience [32] was found to be significantly associated with exposure to mobbing.

Our findings parallel to those of previous studies [1,22,33,37] revealed that mobbing behavior were primarily exerted by the managers and vertical mobbing was the most common type. In accordance with literature $[1,8]$ our results show that while the mobbing behavior towards subordinates from superiors consisted mostly of controlling, preventing communication development, humiliating, damaging self-confidence, unfair evaluation of success, and correspondence, the mobbing behavior among peers consisted of asserting oneself, preventing communication development, and direct assault to prestige, social relationships and health. As reported by
Einarsen [16], the stress involved in trying to fulfill the criteria necessary for advancement in the profession, which becomes more difficult day by day, and a professional career that is based on ambition to achieve status, creates a hidden or open competitive environment, leading to hostility, and negative behavior among peers. As a matter of fact, in our study too, the hostile behavior among peers had come to the point of direct physical violence, against at the victim's health.

Our study revealed out that a great majority $(68.0 \%)$ of the academicians exposed to mobbing had not received professional help after being subjected to psychological violent behavior, they preferred a passive defense strategy against it; they either shared the issue with friends and family, or else internalized mobbing, as if nothing was happening. The results of previous studies [2,38] are similar to ours; most victims (70.0\%) did not tell anyone about what they were going through or stated that sharing with friends was their most common reaction. Due to the traditional hierarchical good manners and for the sake of not risking their profession, academicians perceive the mobbing behavior from their superiors as a situation related to the nature of the profession and as normal in the hierarchical structure, and thus normalize it. It is either for the above mentioned reasons that mobbing is not perceived as an important issue, or else the fact that it is hard to prove harassment, that the victim is driven to fear of not obtaining any results and fear of even being blamed for it $[32,39]$. Nevertheless, in our study, approximately one in every five academicians referred to active defense mechanisms such as informing superiors of harassment, or by taking legal actions. Active reporting rates following mobbing are quite low. Studies report different results. While the results of Yildirim et al. [17], in a study they conducted among academicians in the health sector, showed a reporting rate of $51.0 \%$ in verbal mobbing, Ozcan et al.[40] reported a disclosure rate of mobbing, including verbal mobbing, of $50.0 \%$ and above in a review article comprising all workers in the health sector. On the other hand, Baskan et al. [22] established that only $5.6 \%$ of academicians sought legal redress. Likewise in a study [41] another factor aggravating the problem is the fact that, in our study, one of ten personnel try to solve the psychological violence according to their own methods, therefore leading to uncontrollable situations, as violence leads to more violence. 


\section{Conclusion}

This research found out that workplace mobbing seems to be a critical problem for the academicians in our university. More than half of the academicians are subjected to psychological violence behavior from their own managers and peers. Approximately one out of seven academicians are victims of directly mobbing behaviors. The main mobbers were the managers in an academically superior position. A great majority of the victims resorted to passive defense strategies and the rate of reporting was very low. These findings suggest that this problem has been regarded as a "personal" one in Turkey and that professional health care has not been received. In order to solve vertical and horizontal mobbing, which has personal, social and institutional destructive effects, we suggest an initiation of a reporting system and training activities to gain consciousness and awareness in high-risk groups, for both the perpetrators and victims.

\section{Competing interests}

The authors have no competing interest.

\section{Study Limitations}

Our study has some limitations.

The cross-sectional nature of this study is an important limitation because causal relationship has not been able to be investigated

Another limitation in our study the response rate $(53.0 \%)$ is low. Although the questionnaires were sent by mail to all academicians, 450 out of 850 questionnaires were returned.

The findings of this study cannot be generalized to the universe because the data are limited to the workplaces that participated in the study.

All the measures rely on self-report, which may have recall bias; the extent of psychological violence may have been reported under the actual one.

Despite these limitations, this study gives considerable information about psychological violence occurring among the academics in a university in the central region of Turkey.

\section{References}

1. Leymann H (1996) The Content and development of mobbing at work. EJWOP 5: 165-184.

2. Turkish Parliament Comission Report (2011) Psychological harassment in the workplace (mobbing) and solutions Erişim.

3. Einersan S, Skogstad A (1996) Bullying at work: Epidemiological findings in Public and Private Organizations. EJWOP 5: 185-201.

4. Lutgen-Sandvik P, Tracy SJ, Alberts JK (2007) Burned by bullying in the American work place: prevalence, perception, degree and impact. Journal of Management Studies 44: 837-862.

5. Özkul B, Çarıkcı IH (2010) Mobbing and evaluation of mobbing in terms of Turkish law. Süleyman Demirel University İktisadi ve İdari Bilimler Fakültesi Dergisi 15: 481-489.

6. Tinaz P (2006) Mobbing: Psychological harassment in the workplace (mobbing). Working and Society 4: 13-28.

7. Hirigoyen MF (2000) Spiritual Abuse: Today Deviant Violence (Translated. Bucak H). Istanbul: Actual Publishing.

8. Davenport N, Schwartz RD, Eliot GP (2003) Mobbing: Emotional abuse in the workplace. (Translated. Önertoy, O). Istanbul: Publishing System, 9th. edition
9. Tetik S (2010) Mobbing concept and its importance in terms of individuals and organizations. KMU Sosyal ve Ekonomik Araştırmalar Dergisi 12: 81-89.

10. Akbaş S, Karcioglu F (2010) The relationship between job satisfaction and psychological violence in the workplace.Atatürk Üniversitesi İktisadi ve İdari Bilimler Dergisi 24: 139-161.

11. Matthiesen SB, Einarsen S (2004) Psychiatric distress and symptoms of PTSD among victims of bullying at work. Br J Guid Counc 32: 335-356.

12. Toker GA (2010) Mobbing: Causes of intimidation in the workplace and coping methods. Istanbul: Öğreti yayınları 1.Baskı.

13. Palaz S, Özkan S, Sarı N, Göze F, Akkurt Ö (2008) An analysis of health care employees experiences of mobbing behavior at workplace; A Case study of Southern Marmara Region in Turkey. The Journal of Industrial Relations and Human Resources 10: 43-58.

14. El Gilany A, El-Wehady A, Amr M (2010) Violence against primary health care workers in Al-Hassa, Suudi Arabia. J Interpers Violence 25: 716-34.

15. Kingma M (2001) Workplace violence in the health sector: A Problem of Epidemic Proportion. International Nursing Review 48: 129-130.

16. Einersan S (1996) Harassment and bullying: a review of Scandinavian approach. Aggress Violent Behav 5: 379-401.

17. Yildirim D, Yildirim A (2010) Mobbing behaviors encountered by health science faculties staff and their responses to them. J Med Sci 30: 559-70.

18. Acik Y, Deveci SE, Günes G, Gulbayrak S, Dabak S, et al. (2008) Experience of workplace violence againts general practioners in Turkey. Occup Med Adv Access 58: 361-6.

19. Lewis D (1999) Workplace bullying-/interim findings of a study in further and higher education in Wales. Int J Manpower 20: 106-19.

20. International Labor Office ILO, International Counsel of Nurses ICN, World Health Organization WHO Public Services International PSI. (2002). Workplace violence in the health sector. Framework guidelines for addressing workplace violence in the health sector. Geneva, Switzerland: ILO/ICN/WHO/PSI.

21. Chen WC, Hwu HG, Kung SM, Chiu HJ, Wang JD (2008) Prevalence and determinants of workplace violence of helath care workers in a psychiatric hospital in Taiwan. J Occup Health 50: 288-93.

22. Baskan GA, Cevik SK (2010) According to the academic status of academic staff bullying (mobbing) exposure to behavioral level. XIX. National Congress of Educational Sciences, International Cyprus University, Uluslararası Kıbrıs Üniversitesi, College of Education, Lefkoşa: KKTC.

23. Isık E (2007) Mobbing in business relationships with research on job stres. Yıldız Technical University, Institute of Social Sciences, Istanbul: Master's thesis.

24. Yildirim D, Yıldırım A (2008) Development and psychometric evaluation of workplace psychologically violent behavior instrument. Journal of Clinical Nursing (JCN) 17: 1361-1370.

25. Cogenli MZ, Barlı O (2013) The Exposure of psychological violence (Mobbing) in Universities and an application to the academicians. Procedia-Social and Behavioral Sciences 93: 1174-1178.

26. Hansen AM, Hogh A, Persson R, Karlson B, Gadre AH, et al. (2010) Bullying at work, health outcomes and physiological stress response. Journal of Psychosomatic Research 60: 63-72.

27. Ferrinho P, Biscaia A, Fronteira I, Craveiro I, Antunes AR, Conceicao C, et al. (2003) Patterns of perceptions of workplace violence in the Portuguese health care sector. Hum Resour Health 1:11.

28. Yigitbas Ç, Deveci SE (2012) Mobbing towards health workers. Turkish Medical Association, Journal of Occupational Health and Safety 4: 23-27.

29. Rutherford A, Rissel C (2004) A survey of workplace bullying in a health sector organisation. Aust Health Re 28: 65-72.

30. Salin D (2003) Bullying and organisational politics in competitive and rapidly changing work environments. IJMDM 4: 35-46.

31. Atasoy I (2010) Mobbing in the health sector. A survey of nurses and midwives working in Public and Private Hospitals in Sakarya. Sakarya University, Institute of Social Sciences,Sakarya: Master's Thesis. 
Citation: Senol V, Avsar E, Peksen Akca R, Argun M, Avsarogullari L (2015) Assessment of Mobbing Behaviors Exposed by the Academic Personnel Working in a University, in Turkey . J Psychiatry 18: 212. doi:10.4172/2378-5756.1000212

Page 10 of 10

32. Aytac S, Bozkurt V, Bayram N, Yıldız S, Aytac M (2011) Workplace Violence; A study of Turkish Workers. JOSE 17: 385-402.

33. Agervold M (2007) Bullying at work: A discussion and prevalence based on an empirical study Scandinavian Journal of Psychology 48: 161-172.

34. Quine L (2002) Workplace bullying in junior doctors: Questionnaire survey. BMJ 324: 878 .

35. Altuntas C (2010) A practical study on the concept and examples of mobbing. Yasar University Bulletin.

36. Jackson M, Ashley D (2005) Physical and psychological in Jamaica's Health sector. Rev. Panam Salud Publica18: 114-21.

37. Bilka (2009) Psychological harassment in the workplace: The report of "Mobbing", Ankara,Turkey:Bilka.
38. Cöl SÖ (2008) Psychological violance in the workplace: A research on the hospital workers.Çalışma ve Toplum Dergisi(Working and Society) 4: 107-134.

39. Aydın B, Kartal M, Midik O, Büyükakkus A (2009) Violence againts general practioners in Turkey. J Interpers Violence 24: 1980-94.

40. Ozcan NK, Bilgin H (2011) Violence towards healthcare workers in Turkey: A systematic review. Med Sci, 31: 1442-56.

41. Hesketh KL, Duncan SM, Estabrooks CA, Reimer MA, Giovannetti P, et al. (2003) Workplace violence in Alberta and British Columbia Hospitals. Health Policy 63: 311-21. 